\title{
Standardization of Regeneration Protocol in Wheat-Rye Crosses from Immature Embryos
}

\author{
P. N. Jagadev ${ }^{1 *}$ and V. K. Khanna ${ }^{2}$ \\ ${ }^{1}$ Department of Plant Breeding and Genetics, OUAT, Bhubaneswar, India \\ ${ }^{2}$ Department of Genetics and Plant Breeding, GBPUAT, Pantnagar, India \\ *Corresponding author
}

\begin{abstract}
A B S T R A C T
Keywords

Embryo rescue, Wheat, Rye

Article Info

Accepted:

07 January 2021

Available Online:

10 February 2021

The present investigation was undertaken to standardize the embryo culture technique for plant regeneration from immature embryos in wheat-rye crosses. Embryo rescue was tried to obtain the hybrid plants. At 17-19 days after pollination, the frequency of embryo development showed that wheat cvs. Hope and Highbury were incompatible with both rye cvs. (Russian rye and Rye 8461), while UP 2338 and WH 896 were incompatible with Russian rye only. The compatibility was the highest in the cross of Chinese Spring (CS) with Russian rye. The embryos were cultured on two media combinations, viz., Taira and Larter's modified Norstog's ( $\mathrm{TL}_{1}$ medium) and $\mathrm{TL}_{1}$ medium supplemented with $0.5 \mathrm{mg} / 1$ of naphthalene acetic acid (NAA) and $1.0 \mathrm{mg} / \mathrm{l}$ Kinetin (6-furfuryl amino purine) $\left(\mathrm{TL}_{2}\right.$ medium) following Taira and Larter (1978). Maximum embryo survival (85.0\%) was observed in CS and CS/Hope 5B crosses with Russian rye, when cultured on Taira and Larter's modified Norstog's medium. Hence, it was found that Taira and Larter's modified Norstog's medium was the best for plant regeneration studies in wheat-rye crosses.
\end{abstract}

\section{Introduction}

Although fertilization occurs in many distant hybridizations and embryos begin to develop in relatively a normal way, a number of irregularities subsequently set in, resulting in the eventual death of embryos and collapse of seeds (Raghavan, 1977). Embryo rescue, though not always essential (Kimber and Sallee, 1976), but usually facilitates hybrid production and has been used in many newcrosses involving Triticum, Secale and Hordeum (Fedak, 1978).
Khanna et al., (1994) reported that the best age of hybrid embryos to be rescued from in vivo condition was 17-19 days after pollination in wheat-barley crosses for production of healthy plantlets. The major problems in wheat-rye crosses are poor endosperm development and early abortion of embryos in the process of development. Therefore, the present investigation was designed to standardize the embryo culture technique to rescue the hybrid immature embryos in wheat-rye crosses to get plants. 


\section{Materials and Methods}

The experimental material consisted of five genotypes of hexaploid wheat (Triticum aestivum L.), viz. Chinese Spring (CS), Hope, Highbury, CS/Hope 5B (a substitution line) and UP 2338, a genotype of tetraploid wheat (WH 896) and two genotypes of diploid rye (Secale cereale L.) viz. Rye 8461 and Russian rye. Emasculation was done during the morning and evening hours on randomly selected plants when anthers were still pale green and two days later, when the stigmas were feathery and receptive, the pollinations were performed by hand pollinating the pistils with dusting of pollens from dehiscing anthers of the male parents. After 17-19 days of pollination, the pollinated panicles were detached from the plants and brought to the laboratory for embryo rescue studies. Sterilized seeds were dissected in laminar flow and the embryos were cultured on two media combinations, viz., Taira and Larter's modified Norstog's ( $\mathrm{TL}_{1}$ medium) and $\mathrm{TL}_{1}$ medium supplemented with $0.5 \mathrm{mg} / \mathrm{l}$ of naphthalene acetic acid (NAA) and $1.0 \mathrm{mg} / \mathrm{l}$ Kinetin (6-furfuryl amino purine) ( $\mathrm{TL}_{2}$ medium) following Taira and Larter (1978). After development of roots and shoots, the in vitro cultured plantlets were transferred to a mixture of 3 parts soil and one part farm yard manure.

\section{Results and Discussion}

At 17-19 days after pollination in different wheat-rye crosses, the frequency of embryo development was observed under a dissecting microscope and found that Hope and Highbury were incompatible with both rye cultivars (Russian rye and Rye 8461), while UP 2338 and WH 896 were incompatible with Russian rye only. Among the other crosses, the compatibility was the lowest in UP $2338 \mathrm{x}$ Rye $8461(15.38 \%)$ as against CS x Russian rye $(66.67 \%)$. Russian rye appeared to be more compatible with CS and CS/Hope 5B and Rye 8461 with UP 2338 and WH 896 (Table 1).

Table.1 Embryo development as observed at 17-19 days after pollination
indifferent wheat-rye crosses

\begin{tabular}{|l|l|c|c|c|}
\hline \multicolumn{1}{|c|}{ Variety } & \multicolumn{1}{|c|}{ Cross } & $\begin{array}{c}\text { No. of florets } \\
\text { pollinated }\end{array}$ & $\begin{array}{c}\text { No. of } \\
\text { embryos } \\
\text { obtained }\end{array}$ & $\begin{array}{c}\text { Embryo } \\
\text { development } \\
(\%)\end{array}$ \\
\hline Chinese & x Rye 8461 & $\mathbf{1 8 0}$ & 112 & 62.22 \\
\hline Spring & x Russian rye & $\mathbf{2 4 0}$ & 160 & 66.67 \\
\hline CS/Hope 5B & x Rye 8461 & 260 & 47 & 18.08 \\
\cline { 2 - 5 } & x Russian rye & $\mathbf{2 2 0}$ & 44 & 20.00 \\
\hline \multirow{2}{*}{ Hope } & x Rye 8461 & 240 & 0 & - \\
\cline { 2 - 6 } & x Russian rye & 140 & 0 & - \\
\hline \multirow{2}{*}{ Highbury } & x Rye 8461 & 200 & 0 & - \\
\hline \multirow{2}{*}{ UP 2338 } & x Russian rye & 180 & 0 & - \\
\hline \multirow{2}{*}{ WH 896 } & x Rye 8461 & 260 & 40 & 15.38 \\
\cline { 2 - 6 } & x Russian rye & $\mathbf{2 0 0}$ & 0 & - \\
\hline & x Rye 8461 & 200 & 59 & 29.50 \\
\cline { 2 - 6 } & x Russian rye & 240 & 0 & - \\
\hline
\end{tabular}


Table. 2 Effect of genotypes on growth and development of wheat-rye hybrid embryos in different media (culture period $=3$ weeks) and response of hybrid embryos to various media for direct plantlet formation in different wheat-rye crosses

(culture period $=5$ weeks)

\begin{tabular}{|c|c|c|c|c|c|c|c|c|c|c|}
\hline \multirow[t]{2}{*}{ Cross } & \multirow[t]{2}{*}{ Media } & \multirow{2}{*}{$\begin{array}{l}\text { No.of } \\
\text { embryos } \\
\text { cultured }\end{array}$} & \multirow{2}{*}{$\begin{array}{l}\text { No. of } \\
\text { embryos } \\
\text { showing } \\
\text { growth }\end{array}$} & \multirow{2}{*}{$\begin{array}{c}\text { Embryos } \\
\text { showing } \\
\text { growth } \\
(\%)\end{array}$} & \multirow{2}{*}{$\begin{array}{l}\text { No. of plantlets } \\
\text { obtained after } \\
\text { acclimatization } \\
(\%)\end{array}$} & \multicolumn{4}{|c|}{ Growth characters } & \multirow{2}{*}{$\begin{array}{l}\text { No. of surviving } \\
\text { plantlets after } 2 \\
\text { weeks of transfer } \\
\text { to soil }(\%)\end{array}$} \\
\hline & & & & & & $\begin{array}{l}\text { Shoot } \\
\text { length } \\
\text { (cm) }\end{array}$ & $\begin{array}{l}\text { No. of } \\
\text { leaves }\end{array}$ & $\begin{array}{l}\text { No. of } \\
\text { roots }\end{array}$ & $\begin{array}{l}\text { Root } \\
\text { length } \\
(\mathrm{cm})\end{array}$ & \\
\hline \multirow[t]{2}{*}{ CS x Rye 8461} & $\mathbf{T L}_{1}$ & 20 & 13 & 65.0 & $12(60)$ & 21.2 & 4 & 12 & 5.3 & $8(40)$ \\
\hline & $\mathbf{T L}_{2}$ & 20 & 10 & 50.0 & $9(45)$ & 11.1 & 3 & 10 & 3.3 & - \\
\hline \multirow[t]{2}{*}{ CS x Russian rye } & $\mathbf{T L}_{1}$ & 20 & 17 & 85.0 & $13(65)$ & 17.4 & 4 & 10 & 3.1 & $8(40)$ \\
\hline & $\mathbf{T L}_{2}$ & 20 & 12 & 60.0 & $9(45)$ & 7.7 & 2 & 9 & 3.0 & - \\
\hline \multirow{2}{*}{$\begin{array}{l}\text { CS/Hope 5B x Rye } \\
8461\end{array}$} & $\mathbf{T L}_{1}$ & 20 & 16 & 80.0 & $10(50)$ & 22.5 & 4 & 14 & 4.8 & $7(35)$ \\
\hline & $\mathbf{T L}_{2}$ & 20 & 12 & 60.0 & $8(40)$ & 9.9 & 2 & 11 & 2.0 & - \\
\hline \multirow{2}{*}{$\begin{array}{l}\text { CS/Hope 5B x Russian } \\
\text { rye }\end{array}$} & $\mathbf{T L}_{1}$ & 20 & 17 & 85.0 & $12(60)$ & 16.0 & 4 & 8 & 4.1 & $10(50)$ \\
\hline & $\mathbf{T L}_{2}$ & 20 & 12 & 60.0 & $8(40)$ & 6.8 & 2 & 8 & 2.2 & - \\
\hline \multirow[t]{2}{*}{ UP 2338 x Rye 8461} & $\mathbf{T L}_{1}$ & 20 & 16 & 80.0 & $11(55)$ & 14.5 & 4 & 11 & 3.3 & $9(45)$ \\
\hline & $\mathbf{T L}_{2}$ & 20 & 15 & 75.0 & $8(40)$ & 7.8 & 3 & 10 & 1.9 & - \\
\hline \multirow[t]{2}{*}{ WH 896 x Rye 8461} & $\mathrm{TL}_{1}$ & 20 & 13 & 65.0 & $6(30)$ & 14.0 & 4 & 7 & 4.2 & $3(15)$ \\
\hline & $\mathbf{T L}_{2}$ & 20 & 13 & 65.0 & $4(20)$ & 7.3 & 2 & 6 & 2.7 & - \\
\hline \multirow[t]{2}{*}{ Total } & $\mathbf{T L}_{1}$ & 120 & 92 & 76.7 & $64(53)$ & \multicolumn{4}{|c|}{$\begin{array}{l}\text { Healthy Plantlets with multiple } \\
\text { shoot and root formation. }\end{array}$} & $45(38)$ \\
\hline & $\mathbf{T} \mathbf{L}_{2}$ & 120 & 74 & 61.7 & $46(38)$ & \multicolumn{4}{|c|}{$\begin{array}{l}\text { Shoot formation started after } \\
\text { alround callusing, but growth } \\
\text { inhibited with occasional shoot } \\
\text { proliferation. }\end{array}$} & - \\
\hline
\end{tabular}

$\mathrm{TL}_{1}=$ Taira and Larter's medium, $\mathrm{TL}_{2}=\mathrm{TL}_{1}+\mathrm{NAA}(0.5 \mathrm{mg} / \mathrm{l})+$ Kinetin $(1.0 \mathrm{mg} / \mathrm{l})$ 
Fig.1 Stages of in vitro development of embryos rescued from different wheat-rye crosses: (A) CS/Hope 5B x Russian rye showing shoot and root development after 3 weeks of embryo culture on $\mathrm{TL}_{1}$ medium; (B) CS/Hope 5B x Russian rye showing callus after 3 weeks of embryo culture on $\mathrm{TL}_{2}$ medium; (C) Plantlets from CS/Hope 5B x Rye 8461 after 5 weeks of embryo culture on $\mathrm{TL}_{1}$ and $\mathrm{TL}_{2}$ media (L-R); (D) Root and shoot development after 5 weeks of embryo culture in CS/Hope 5B x Rye 8461 on $\mathrm{TL}_{1}$, CS x Rye 8461 on $\mathrm{TL}_{1}$ and $\mathrm{TL}_{2}$ and $\mathrm{WH} 896$ x Rye 8461 on $\mathrm{TL}_{1}$ media (L-R); (E) Hybrid plantlets in liquid medium covered with a glass beaker and (F) Hybrid plantlets transferred to soil in plastic pots
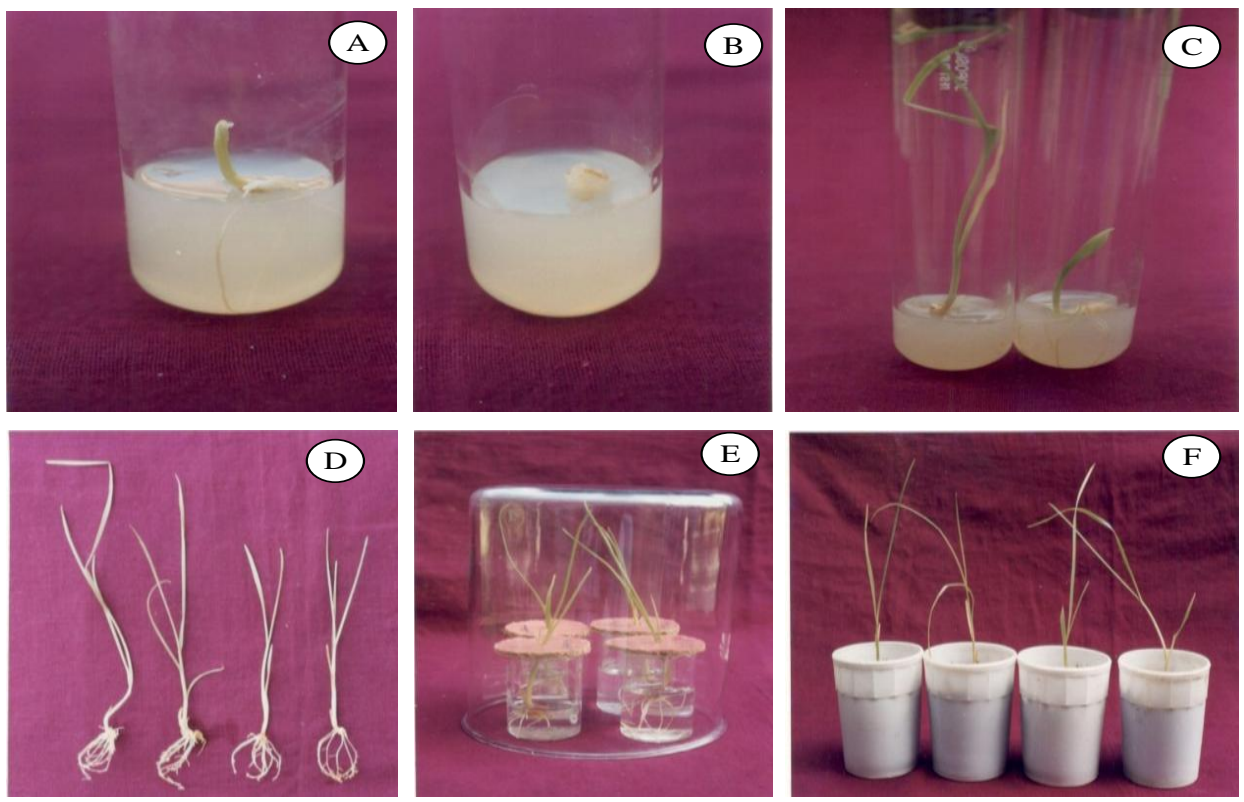

In the present investigation, an attempt was made to find out the medium suitable for the particular genotypes of wheat and rye under artificial conditions. Out of the two different media combinations, the basal Taira and Larter's medium $\left(\mathrm{TL}_{1}\right)$ proved to be the best giving 76.7 per cent embryo growth while $\mathrm{TL}_{1}$ supplemented with NAA $0.5 \mathrm{mg} / \mathrm{l}$ and kinetin $1.0 \mathrm{mg} / \mathrm{l}\left(\mathrm{TL}_{2}\right.$ medium) showed less embryo growth, i.e. 61.7 per cent. The hybrid embryos obtained from different genotypes of wheat and rye showed a different growth response, when cultured on different TL media combinations. A maximum embryo survival (85.0 per cent) was observed in CS and $\mathrm{CS} /$ Hope $5 \mathrm{~B}$ crosses with Russian rye when cultured on $\mathrm{TL}_{1}$ medium (Fig. 1A), while the minimum embryo survival (50.0 per cent) was observed in CS crosses with Rye 8461 when cultured on $\mathrm{TL}_{2}$ medium (Table
2). Alround callusing was observed in some cases of $\mathrm{CS} /$ Hope $5 \mathrm{~B}$ crosses with both rye genotypes (Fig. 1B). A critical consideration in embryo culture is the composition of the culture media, but Raghavan (1977), Yeung et al., (1981) and Monnier (1978) felt that hormonal supplements were not necessary for embryo culture as embryos possess an endogenous hormone supply. Neverthless, Raghavan (1980) felt that hormones might have a profound influence on embryo development. Tikhenko et al., (2017) reported that the changes in the reproductive barrier between hexaploid wheat and rye could be induced using in situ embryo rescue of abnormal embryos, yielding stable fertile amphidiploid plants.

A wide range of difference (20-65 per cent) was observed among the crosses and culture 
media for plantlet formation potential. The highest plantlet formation frequency of 65.0 per cent was observed in CS x Russian rye on $\mathrm{TL}_{1}$ medium and the minimum frequency of 20.0 per cent was noticed in WH 896 x Rye 8461 on $\mathrm{TL}_{2}$ medium (Table 2). The hybrid embryos cultured on $\mathrm{TL}_{1}$ medium showed a better development of shoots, leaves and roots (Fig. 1C). Plantlets resulting from the embryos of CS/Hope 5B x Rye 8461, when cultured on $\mathrm{TL}_{1}$ medium, showed maximum shoot length, number of leaves and roots (Table 2). Stunted shoot growth and lack of root formation were the most common abnormalities on $\mathrm{TL}_{2}$ medium. After 4 to 5 weeks of culture, the hybrid embryos cultured on $\mathrm{TL}_{1}$ medium only were ready for acclimatization as they attained more than 12 $\mathrm{cm}$ in shoot length with 2-3 leaves and small primary roots (Fig. 1D). Then, the plantlets were transferred to liquid medium in culture vessels having $1 / 10^{\text {th }}$ strength of inorganic salts of $\mathrm{TL}_{1}$ medium and covered with a glass beaker to maintain high humidity (Fig. 1E).

After a week, when the new roots emerged, the plantlets were transferred to soil (Fig. 1F). Out of 240 embryos cultured onTL $\mathrm{T}_{1}$ and $\mathrm{TL}_{2}$ media, 63 were transferred to soil. But after 2 weeks of transfer to soil, only 45 plantlets survived $(38.0 \%)$ with a maximum survival percentage of 50.0 observed in CS/Hope $5 \mathrm{~B}$ x Russian rye (Table 2). Hence, it was found that Taira and Larter's modified Norstog's medium $\left(\mathrm{TL}_{1}\right)$ was the best for plant regeneration studies in wheat-rye crosses.

\section{References}

Fedak, G. 1978. Barley monoploids and hybrids from barley $\mathrm{x}$ rye crosses. In: Interspecific hybridization in plant breeding (eds. Sanchez-Monge, E. and GarciaOlmedo, F.). Proc. $8^{\text {th }}$ EUCARPIA Cong., Madrid, Olmedo, 59: 9-14.

Khanna, V.K., Dhaubhadel, S., Kodali, S. and Garg, G.K. 1994. Effect of hormones on wheat-barley crosses, embryo rescue and mitotic and isozymic studies in hybrids. Curr. Sci., 67: 1003-1012.

Kimber, G. and Sallee, P.J. 1976. A hybrid between Triticum timopheevi and Hordeum bogdanik. Cereal Res. Commu. 4: 33-37.

Monnier, M. 1978. Culture of zygotic embryos. In: Frontiers of Plant Tissue Culture (ed. Thorpe, T.A.), Calgary University Press, Calgary, pp.277-286.

Raghavan, V. 1980. Embryo culture. Intl. Rev. Cytol. Suppl.11B: 209-240.

Raghavan, V. 1977. Applied aspects of embryo culture. In: Plant Cell, Tissue and Organ Culture, Springer, New York. pp. 375397.

Taira, T. and Larter, E.N. 1978. Factors influencing development of wheat-rye hybrid embryos in vitro. Crop Sci.18: 348-350.

Tikhenko, N., Rutten, T., Senula, A., Rubtsova, M., Keller, E.R.J. and Borner, A. 2017. The changes in the reproductive barrier between hexaploid wheat (Triticum aestivum L.). and rye (Secale cereale L.): different states lead to different fates. Planta.246: 377-388.

Yeung, E.C., Thorpe, T.A. and Jensen C.J. 1981. In vitro fertilization and embryo culture. In: Plant Tissue Culture: methods and application in Agriculture (ed. Thrope, T.A.). Academic Press, New York. pp. 253-271.

\section{How to cite this article:}

Jagadev, P. N. and Khanna, V. K. 2021. Standardization of Regeneration Protocol in Wheat-Rye Crosses from Immature Embryos. Int.J.Curr.Microbiol.App.Sci. 10(02): 533-537. doi: https://doi.org/10.20546/ijcmas.2021.1002.063 